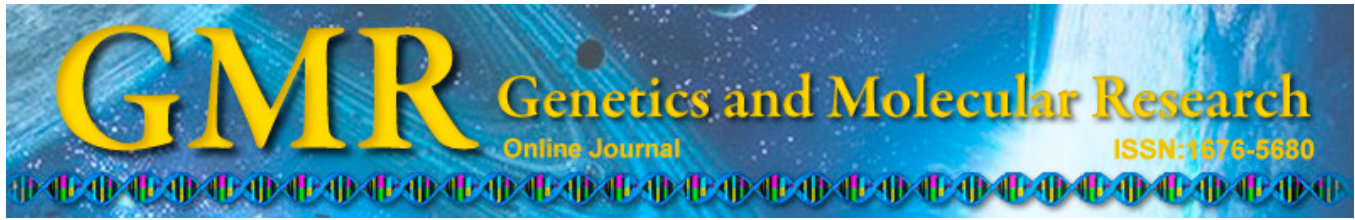

\title{
Single nucleotide polymorphisms of $\Delta 6$-desaturase and Elovl5 segments and their associations with common carp (Cyprinus carpio) growth traits
}

\author{
H. Ren ${ }^{1,2}$, J. Yu ${ }^{1}$, P. Xu ${ }^{1}$ and Y. Tang ${ }^{1}$
}

${ }^{1}$ Key Laboratory of Genetic Breeding and Aquaculture Biology of Freshwater Fishes, Ministry of Agriculture, Freshwater Fisheries Center, Chinese Academy of Fishery Sciences, Wuxi, Jiangsu, China

${ }^{2}$ Animal Science and Technology College,

Henan University of Science and Technology, Luoyang, Henan, China

Corresponding author: J. Yu

E-mail: yujh@ffrc.cn

Genet. Mol. Res. 14 (4): 12848-12854 (2015)

Received January 14, 2015

Accepted May 15, 2015

Published October 21, 2015

DOI http://dx.doi.org/10.4238/2015.October.21.4

\begin{abstract}
Highly unsaturated fatty acids (HUFAs) are crucial for the nutritional health, physiology, and reproduction of vertebrates. The $\Delta 6$-desaturase and Elov15 elongase genes produce essential enzymes in the biosynthetic pathway of HUFAs. Single nucleotide polymorphism (SNP) analysis of genes functionally related to the growth traits of the common carp (Cyprinus carpio var. Jian) can provide useful information for common carp molecular breeding. In this study, we isolated two $\Delta 6 \mathrm{Fad}$ genes and two Elovl5 genes from the common carp. Polymerase chain reaction-restriction fragment length polymorphism was performed, and the genotypes of three SNPs $(\triangle 6 \mathrm{Fad}-\mathrm{a}$ intron 10 C73T, $\triangle 6$ Fad-b intron 10_A56G, and Elov15-a intron 5_C64A) in 712 individuals (383 females and 329 males) were detected. Correlation analysis between the genotypes and weight gain revealed that intron
\end{abstract}


$10 \_\mathrm{C} 73 \mathrm{~T}$ of $\triangle 6 \mathrm{Fad}-\mathrm{a}$, intron $10 \_\mathrm{A} 56 \mathrm{G}$ of $\triangle 6 \mathrm{Fad}-\mathrm{b}$, and intron 5 C64A of Elovl5-a were significantly associated with common carp weight gain. Weight gain increased with the enrichment of molecular SNP markers, consistent with the characteristics of quantitative traits. Our results indicate that $\triangle 6 \mathrm{Fad}$ and Elovl5 elongase genes could be candidate genes for the molecular breeding of the common carp. This study provides useful information for the improvement of this species.

Key words: $\Delta 6$-desaturase; Elovl5; Cyprinus carpio var. Jian; INTRODUCTION Single nucleotide polymorphism; Growth trait

Fish are an important source of n-3 highly unsaturated fatty acids (HUFAs), which have beneficial health effects in humans (Eilander et al., 2007; Ruxton et al., 2007). The biosynthesis of HUFAs in fish involves the sequential desaturation and elongation of precursor $\mathrm{C}_{18}$ polyunsaturated fatty acids (PUFAs), $\Delta 6$-desaturase, and Elovl5 elongase, which are crucial enzymes in the biosynthetic pathway of HUFAs (Tocher et al., 2004; Zheng et al., 2004). $\Delta 6$-desaturase catalyzes the insertion of double bonds at the $\Delta 6$ position in the carbon backbone, and Elovl5 elongase is responsible for the pre-existing chain (Jakobsson et al., 2006).

The identification of molecular genetic markers for growth rate is attracting increasingly more attention in the selective breeding of fish. Once an association between a DNA polymorphism and a trait is found, this polymorphism is considered a potential genetic marker for marker-assisted selection (MAS) programs. Genetic markers that are either linked to loci that affect economically important traits, or have a direct effect themselves, can be used to genetically improve animals.

The common carp (Cyprinus carpio var. Jian) is farmed throughout China. As part of a MAS program to improve growth rate in the species, growth-related genes, such as myostatin and growth hormone receptor, have been studied in our laboratory, and we have identified growthrate markers (Yu et al., 2010, 2011). However, no studies on the common carp $\Delta 6$-desaturase and Elovl5 elongase genes have been conducted, despite it having been extensively studied.

Although association studies cannot determine whether gene markers are responsible for variations in a trait or variations are due to closely linked loci that affect the trait, there is evidence to suggest that the gene affects the trait. Therefore, the aim of the present study was to identify polymorphisms in the $\Delta 6$-desaturase and Elovl5 elongase genes, and to analyze associations between the polymorphisms and growth rate in the common carp. The results of this study may provide a better understanding of the effects of $\Delta 6$-desaturase and Elovl5 elongase genes on common carp growth traits.

\section{MATERIAL AND METHODS}

\section{Fish sampling}

A total of 712 individuals, including 383 females and 329 males, were passive integrated transponder-tagged and used in the experiment after four months of breeding. All of the fish were fed in the same pond at the Yi Xing site of the Freshwater Fisheries Research Center, Chinese Academy of Fishery Science. Body weight was recorded at two and 15 months after tagging, and venous blood was collected for genomic DNA extraction. 


\section{DNA extraction}

Genomic DNA was extracted using the classic phenol-chloroform method (Sambrook et al., 1989) and preserved in TE buffer. DNA was examined by performing $1 \%$ agarose gel electrophoresis, and concentrations were determined using photometry (Eppendorf, German). The working DNA concentration was $50 \mathrm{ng} / \mu \mathrm{L}$.

\section{Isolation of $\Delta 6$-desaturase and Elovl5 segments}

Primers were designed based on $\Delta 6$-desaturase and Elovl5 genomic sequences (data not shown) (Table 1). JLFAD-E9F and JLFAD-I11R-a were used to amplify partial exon 9, intron 9, exon 10, intron 10, and partial exon 11 of $\triangle 6 \mathrm{Fad}-\mathrm{a}$, and JLFAD-E9F and JLFADI11R-b were used to amplify partial exon 9, intron 9, exon 10, intron 10, and partial exon 11 of $\triangle 6$ Fad-b. JLELO-E5F-A and JLELO-E6R-A were used to amplify partial exon 5, intron 5 , and partial exon 6. The primer sequences are shown in Table 1. Polymerase chain reaction (PCR) amplifications using the primers and Taq DNA polymerase (Takara, Japan) were performed with an initial denaturation at $94^{\circ} \mathrm{C}$ for $2 \mathrm{~min}, 30$ cycles of denaturation at $94^{\circ} \mathrm{C}$ for $30 \mathrm{~s}$, annealing at $\mathrm{Tm}$ (annealing temperature according to different primers) for $30 \mathrm{~s}$, and extension at $72^{\circ} \mathrm{C}$ for $1 \mathrm{~min}$, followed by a final extension at $72^{\circ} \mathrm{C}$ for $8 \mathrm{~min}$. The gel-purified PCR products were cloned into a pMD18-T vector (Takara, Japan), and positive clones were sequenced by Biosune Inc., Shanghai, China.

\begin{tabular}{|c|c|c|c|}
\hline Primer & Sequence $\left(5^{\prime} \rightarrow 3^{\prime}\right)$ & $\operatorname{Tm}\left({ }^{\circ} \mathrm{C}\right)$ & Product \\
\hline JLFAD-E9F & CAGATGAGCCACATCCCCATG & 57.3 & Partial E9, I9, E10, I10, partial E11 \\
\hline JLFAD-I11R-A & CACTGGCGCCTTCTGCAAGAA & 60.0 & \\
\hline JLFAD-E9F & CAGATGAGCCACATCCCCATG & 57.3 & Partial E9, I9, E10, I10, partial E11 \\
\hline JLFAD-I11R-B & ATAGGAATAGTTCGGAGCAAGAGCAC & 57.5 & \\
\hline JLELO-E5F-A & ATCTTCTGATTGTGTGGATGGGACC & 59 & Partial E5, I5, partial E6 \\
\hline JLELO-E6R-A & GTGAAATGTGACATGCTCTTGACAGG & 58.7 & \\
\hline
\end{tabular}

I, intron; E, exon.

\section{Screening for polymorphic sites}

Primers designed according to the above sequences were used to amplify DNA from 10 randomly chosen fish (Table 1). The amplified fragments were sequenced and aligned using Clustal W (Thompson et al.,1994). A locus was considered to be an SNP site if it had an alternative base in four or more animals of the 10 samples. JLFAD-E9F-a and JLFAD-I11R-a were used to screen for SNP sites in intron 9, exon 10, and intron 10 of $\triangle 6$-Fad-a; JLFAD-E9F and JLFAD-I11R-b were used to screen for SNP sites in intron 9, exon 10, and intron 10 of $\triangle 6$-Fad-b; and JLELO-E5F-A and JLELO-E6R-A were used to screen for SNP sites in partial exon 5, intron 5, and partial exon 6 of Elovl5-a. We designed the primers to examine three SNP sites by PCR-restriction fragment length polymorphism (PCR-RFLP) (Table 2). The 5- $\mu \mathrm{L}$ PCR product was mixed with $0.15 \mu \mathrm{L}$ endonuclease, $1.0 \mu \mathrm{L}$ buffer, and $3.85 \mu \mathrm{L} \mathrm{ddH}_{2} \mathrm{O}$, and digested at a temperature that was dependent on the enzyme used for between 4 and $6 \mathrm{~h}$. The digestion product was then separated by $2 \%$ agarose gel electrophoresis to determine the allele type. 
Table 2.Primers, restriction enzymes, and restriction fragments of single- nucleotideloci.

\begin{tabular}{llll}
\hline Gene region & Primer and sequence $\left(5^{\prime} \rightarrow 3^{\prime}\right)$ & Restriction enzyme and temperature & Length of restriction fragment \\
\hline$\Delta 6-$ Fad-a & F: ACGCATCACAGAACTGCGTATGTG & HpyF3I, $37^{\circ} \mathrm{C}$ & CC: 809 \\
I-10_C73T & R: TGCTTAAACCAGTGCGGCTGT & & TT: 221,588 \\
$\Delta 6-$-Fad-b & F: CAGTCGCATGACTGTGGTGTGAATG & Hhal, $37^{\circ} \mathrm{C}$ & GG: 352,67 \\
I-10_A56G & R: CGCCAGTAATTGTGCCGAGGC & & AA: 419 \\
Elov15-a & F: ACTGTGTAAGTGGAAAATCAGAAGTGGG & TasI, $65^{\circ} \mathrm{C}$ & AA: $373,208,239$ \\
I-5_C64A & R: CACCATTCGATTCGATTCACATTC & & CC: 581,239 \\
\hline
\end{tabular}

\section{Sequence analysis and data processing}

Sequences were assembled using DNASTAR (Lasergene, San Francisco, CA, USA), and aligned with Clustal W (Thompson et al., 1994). A general linear model in SPSS17.0 (SPSS Inc., USA) was used to analyze relationships between the alleles and growth traits.

\section{RESULTS}

\section{Analysis of 46 -desaturase and Elovl5 and screening for polymorphic sites}

Based on the results of a preliminary experiment, two $\Delta 6$-desaturase $(\Delta 6 \mathrm{Fad}$-a and $\Delta 6 \mathrm{Fad}-\mathrm{b}$ ) and two Elovl5 (Elov15-a and Elovl5-b) genomic DNA fragments were cloned from the common carp. Segments of the $\Delta 6 \mathrm{Fad}-\mathrm{a}, \Delta 6 \mathrm{Fad}-\mathrm{b}$, and Elovl5-a genomic sequences were amplified from 10 randomly selected carp and aligned with Clustal W. Sites with an alternative base in four or more samples were counted as valid SNP sites. We identified nineteen SNPs in the $\triangle 6 \mathrm{Fad}$-a segment, seven in the $\Delta 6 \mathrm{Fad}-\mathrm{b}$ segment, and six in the Elov15-a segment. Three SNPs were examined using the PCR-RFLP technique, one in intron 10_C73T of $\triangle 6 \mathrm{Fad}-\mathrm{a}$, two in intron $10 \_\mathrm{A} 56 \mathrm{G}$ of $\triangle 6 \mathrm{Fad}-\mathrm{b}$, and one in intron 5_C64A of Elovl5-a (Figure 1).

\section{Assessment of polymorphic loci and associations with body weight}

Relationships between the genotypes and body weight were investigated in 712 samples (Table 3). Significant differences were found in intron 10_C73T of $\triangle 6 \mathrm{Fad}$-a between the genotypes and body weight. Multiple comparison results indicated that individuals with the TT genotype were significantly heavier than those with the CC genotype $(\mathrm{P}<0.05)$. Significant differences were also found in intron $10 \_$A56G of $\triangle 6 \mathrm{Fad}-\mathrm{b}$ between the genotypes and body weight. Multiple comparison results indicated that individuals with the GG genotype were significantly heavier than those with the AA genotype $(\mathrm{P}<0.01)$. Significant differences were found in intron 5_C64A of Elovl5-a between the genotypes and body weight. Multiple comparison results indicated that individuals with the $\mathrm{CC}$ genotype were significantly heavier than those with the AA genotype $(\mathrm{P}<0.05)$. 
A

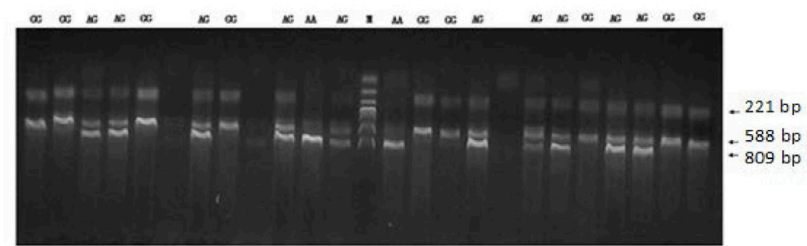

B
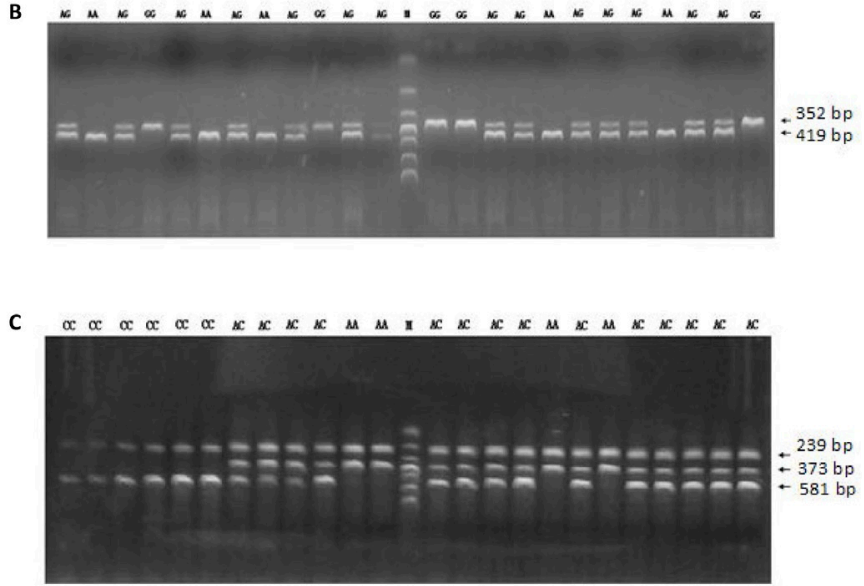

Figure 1. Electrophoresis patterns of different genotypes in three single nucleotide polymorphic loci. A. $\Delta 6-\mathrm{Fad}-\mathrm{a}$, I-10 C73T; B. $\Delta 6$-Fad-b, I-10 A56G; C. Elovl5-a, I-5 C64A.

Table 3. Correlations between $\Delta 6$-desaturase and Elovl5 genotypes and weight gain in Cyprinus carpio (mean $\pm \mathrm{SE})$.

\begin{tabular}{|c|c|c|c|c|c|}
\hline \multirow[t]{2}{*}{ SNP locus } & \multirow[t]{2}{*}{ Genotype } & \multicolumn{2}{|c|}{ Juvenile } & \multicolumn{2}{|c|}{ Adult } \\
\hline & & Male & Female & Male & Female \\
\hline \multirow[t]{3}{*}{$\Delta 6$-Fad-a I-10_C73T } & $\mathrm{CC}$ & $\begin{array}{c}98.48 \pm 8.64 \\
(\mathrm{n}+113)\end{array}$ & $\begin{array}{c}91.57 \pm 3.19^{\mathrm{b}} \\
(\mathrm{n}+101)\end{array}$ & $\begin{array}{c}648.77 \pm 10.68^{b} \\
(n+113)\end{array}$ & $\begin{array}{c}769.65 \pm 12.49^{b} \\
(n+101)\end{array}$ \\
\hline & $\mathrm{CT}$ & $\begin{array}{c}96.56 \pm 3.03 \\
(\mathrm{n}+88)\end{array}$ & $\begin{array}{c}106.60 \pm 3.36^{\mathrm{a}} \\
(\mathrm{n}+76)\end{array}$ & $\begin{array}{c}671.05 \pm 15.34^{\mathrm{ab}} \\
(\mathrm{n}+88)\end{array}$ & $\begin{array}{c}815.83 \pm 20.69^{\mathrm{ab}} \\
(\mathrm{n}+76)\end{array}$ \\
\hline & $\mathrm{TT}$ & $\begin{array}{c}101.20 \pm 3.59 \\
(\mathrm{n}+81)\end{array}$ & $\begin{array}{c}110.52 \pm 4.49^{\mathrm{a}} \\
(\mathrm{n}+79)\end{array}$ & $\begin{array}{l}696.60 \pm 15.58^{\mathrm{a}} \\
(\mathrm{n}+81)\end{array}$ & $\begin{array}{c}853.49 \pm 18.29^{\mathrm{a}} \\
(\mathrm{n}+79)\end{array}$ \\
\hline $\mathrm{P}$ & & 0.891 & $<0.001$ & 0.045 & 0.002 \\
\hline \multirow[t]{3}{*}{$\Delta 6$-Fad-b I-10_A56G } & AA & $\begin{array}{l}92.87 \pm 7.81 \\
(\mathrm{n}+128)\end{array}$ & $\begin{array}{c}92.02 \pm 3.49^{\mathrm{b}} \\
(\mathrm{n}+95)\end{array}$ & $\begin{array}{l}634.88 \pm 9.52^{\mathrm{b}} \\
(\mathrm{n}+128)\end{array}$ & $\begin{array}{c}769.75 \pm 13.89^{\mathrm{b}} \\
(\mathrm{n}+95)\end{array}$ \\
\hline & AG & $\begin{array}{c}98.31 \pm 2.75 \\
(\mathrm{n}+108)\end{array}$ & $\begin{array}{c}100.71 \pm 3.54^{\mathrm{b}} \\
(\mathrm{n}+97)\end{array}$ & $\begin{array}{l}650.55 \pm 11.87^{\mathrm{b}} \\
(\mathrm{n}+108)\end{array}$ & $\begin{array}{c}799.64 \pm 17.17^{\mathrm{b}} \\
(\mathrm{n}+97)\end{array}$ \\
\hline & GG & $\begin{array}{l}102.91 \pm 3.32 \\
(\mathrm{n}+76)\end{array}$ & $\begin{array}{c}112.87 \pm 3.54^{\mathrm{a}} \\
(\mathrm{n}+79)\end{array}$ & $\begin{array}{c}736.13 \pm 16.63^{\mathrm{a}} \\
(\mathrm{n}+76)\end{array}$ & $\begin{array}{c}868.26 \pm 17.45^{\mathrm{a}} \\
(\mathrm{n}+79)\end{array}$ \\
\hline $\mathrm{P}$ & & 0.059 & $<0.001$ & $<0.001$ & $<0.001$ \\
\hline \multirow[t]{3}{*}{ Elovl5-a I-5_C64A } & AA & $\begin{array}{c}93.21 \pm 2.71^{\mathrm{b}} \\
(\mathrm{n}+126)\end{array}$ & $\begin{array}{c}99.44 \pm 4.12 \\
(\mathrm{n}+103)\end{array}$ & $\begin{array}{c}643.23 \pm 9.59 \\
(\mathrm{n}+126)\end{array}$ & $\begin{array}{c}763.48 \pm 25.74^{b} \\
(n+103)\end{array}$ \\
\hline & $\mathrm{CA}$ & $\begin{array}{c}98.26 \pm 2.38^{b} \\
(\mathrm{n}+152)\end{array}$ & $\begin{array}{c}98.68 \pm 3.18 \\
(\mathrm{n}+127)\end{array}$ & $\begin{array}{c}666.55 \pm 10.42 \\
(\mathrm{n}+152)\end{array}$ & $\begin{array}{c}822.15 \pm 12.83^{\mathrm{ab}} \\
(\mathrm{n}+127)\end{array}$ \\
\hline & $\mathrm{CC}$ & $\begin{array}{c}109.26 \pm 8.16^{\mathrm{a}} \\
(\mathrm{n}+32)\end{array}$ & $\begin{array}{c}106.32 \pm 4.95 \\
(\mathrm{n}+41)\end{array}$ & $\begin{array}{l}679.48 \pm 27.52 \\
\quad(\mathrm{n}+32)\end{array}$ & $\begin{array}{c}833.69 \pm 24.13^{\mathrm{a}} \\
(\mathrm{n}+41)\end{array}$ \\
\hline $\mathrm{P}$ & & 0.036 & 0.515 & 0.177 & 0.046 \\
\hline
\end{tabular}

Within the same column, different letters indicate a significant difference at $\mathrm{P}<0.05$. SNP, single nucleotide polymorphism. 


\section{Marker enrichment and body weight}

The present study identified three markers that were associated with weight gain (Table 4). Individuals with the TT genotype in intron $10 \_C 73 \mathrm{~T}$ of $\triangle 6 \mathrm{Fad}-\mathrm{a}$, the GG genotype in intron 10_A56G of $\triangle 6 \mathrm{Fad}-\mathrm{b}$, and the CC genotype in intron 5_C64A of Elovl5-a gained more weight than individuals with other genotypes. We also found significant differences between individuals with different numbers of markers: individuals with three markers were significantly heavier than those with one or no markers $(\mathrm{P}<0.01)$.

Table 4. Effect of marker enrichment on weight gain.
\begin{tabular}{lccc}
\hline Number of markers & Juvenile weight gain & Adult weight gain & Sample size \\
\hline 0 & $92.18 \pm 2.65^{\mathrm{b}}$ & $722.38 \pm 13.33^{\mathrm{b}}$ & 130 \\
1 & $100.15 \pm 1.43^{\mathrm{b}}$ & $749.45 \pm 7.42^{\mathrm{b}}$ & 504 \\
2 & $104.62 \pm 3.93^{\mathrm{ab}}$ & $802.73 \pm 21.44^{\mathrm{ab}}$ & 68 \\
3 & $118.96 \pm 5.43^{\mathrm{a}}$ & $838.08 \pm 34.30^{\mathrm{a}}$ & 9 \\
$\mathrm{P}$ & 0.007 & 0.004 & \\
\hline
\end{tabular}

Within the same column, different letters indicate a significant difference at $\mathrm{P}<0.05$.

\section{DISCUSSION}

The $\Delta 6$-desaturase and Elovl5 elongase gene DNA fragment sequences were spliced and isolated, while the $\triangle 6 \mathrm{Fad}-\mathrm{a}$ and $\triangle 6 \mathrm{Fad}-\mathrm{b}$ DNA sequences were cloned, both being comprised of 13 exons and 12 introns, and the Elovl5-a and Elovl5-b DNA sequences were also cloned, both being comprised of eight coding exons and seven introns. Segments of $\Delta 6 \mathrm{Fad}-\mathrm{a}$, $\Delta 6 \mathrm{Fad}-\mathrm{b}$, and Elovl5-a were isolated, and SNP loci were detected using three primer pairs (Table 1). The exon sequences were very similar, but the introns differed in size; however, the $5^{\prime}$ and $3^{\prime}$ ends of the introns contained similar sequences. Intron termini are highly conserved, because they are important for RNA splicing (Fedorova and Fedorov, 2003). A total of 32 polymorphic loci were found in $\Delta 6 \mathrm{Fad}-\mathrm{a}, \Delta 6 \mathrm{Fad}-\mathrm{b}$, and Elovl5-a; 26 were found in the introns, whereas only six were found in the exons, which indicates that there was greater variation in the introns than in the exons.

Three loci were genotyped using PCR-RFLP, and the positive results confirmed that this method could accurately identify genotypes. However, this method requires specific primers, and RFLP also requires a restriction site. Therefore, it may not be suitable for all loci, particularly for loci in introns, as they may contain many repetitive sequences and have a higher AT content. Although many other methods exist, including gene chips and probes for high-throughput SNP analysis, they are expensive and require special equipment. Therefore, it is necessary to develop other detection methods.

Dietary long-chain PUFAs are very important to the nutritional health, physiology, and reproduction of vertebrates (Burr, 1981; Simopoulos, 2000), and are crucially important during early development because of the profound morphological and physiological changes that occur (Tocher et al., 2003). HUFAs have long been recognized as essential components of fish larval diets (Sargent et al., 1999), and play both energetic and structural roles, depending on the class of lipid molecule that they are incorporated in. $\Delta 6$-desaturase and Elov15 elongase are critical enzymes in the biosynthetic pathway of HUFAs (Tocher et al., 2004; Zheng et al., 2004), and may affect growth and development in fish. In the present study, three loci that 
were closely related to juvenile and adult carp growth rates were examined. Individuals with mutated genotypes grew faster than those with other genotypes, and those with three markers were heavier than those with one or no markers. Therefore, $\Delta 6 \mathrm{Fad}-\mathrm{a}, \Delta 6 \mathrm{Fad}-\mathrm{b}$, and Elovl5-a play an important role in the common carp. Our results suggest that it is feasible to select molecular makers from candidate genes. In addition, because growth is a quantitative trait that is controlled by multiple genes, markers in other genes that control growth, appetite, muscle development, and cell proliferation should also be selected. To stabilize and develop a high-quality strain, it is necessary to adhere to pedigree selection, and to develop more markers for growth.

In conclusion, this is the first study to report an association between $\Delta 6$-desaturase and Elov15 elongase genes and growth traits in the common carp, and will provide useful information for the improvement of this species.

\section{ACKNOWLEDGMENTS}

Research supported by the National High Technology Research and Development Program of China ("863" program, \#2011AA100400), the Key Laboratory of Freshwater Fisheries and Germplasm Resources Utilization, the Ministry of Agriculture Funds (\#KF201312), the Education Department of Henan Province (\#14B240006), and the Doctor Research StartUp Fund of Henan University of Science and Technology (\#09001760).

\section{REFERENCES}

Burr GO (1981). The essential fatty acids fifty years ago. Prog. Lipid Res. 20: 27-29.

Eilander A, Hundscheid DC, Osendarp SJ, Trander C, et al. (2007). Effects of n-3 long chain polyunsaturated fatty acid supplementation on visual and cognitive development throughout childhood: A review of human studies. Prostaglandins Leukot. Essent. Fatty Acids 76: 189-203.

Fedorova L and Fedorov A (2003). Introns in gene evolution. Genetica 118: 123-131.

Jakobsson A, Westerberg R and Jacobsson A (2006). Fatty acid elongases in mammals: their regulation and roles in metabolism. Prog. Lipid Res. 45: 237-249.

Ruxton CHS, Reed SC, Simpson MJA and Millington KJ (2007). The health benefits of omega-3 polyunsaturated fatty acids: a review of the evidence. J. Hum. Nutr. Diet 20: 275-285.

Sambrook J, Fritsch E and Maniatis T (1989). Molecular cloning: a laboratory manual. Cold Spring Harbor Laboratory Press, Cold Spring Harbor.

Sargent J, McEnvoy L, Estevez A, Bell G, et al. (1999). Lipid nutrition of marine fish during early development: current status and future directions. Aquaculture 179: 217-229.

Simopoulos AP (2000). Human requirements for n-3 polyunsaturated fatty acids. Poult. Sci. 79: 961-970.

Thompson JD, Higgins DG and Gibson JF (1994). CLUSTALW: improving the sensitivity of progressive multiple sequence alignment through sequence weighing, position-specific gap penalties and weight matrix choice. Nucleic Acids Res. 22: 4673-4680.

Tocher DR, Bell JG, McGhee F, Dick JR, et al. (2003). Effects of dietary lipid level and vegetable oil on fatty acid metabolism in Atlantic salmon (Salmo salar) over the entire production cycle. Fish Physiol. Biochem. 29: 193-209.

Tocher DR, Fonseca-Madrigal J, Dick JR, Ng W, et al. (2004). Effects of water temperature and diet containing palm oil on fatty acid desaturation and oxidation in hepatocytes and intestinal enterocytes of rainbow trout (Oncorhynchus mykiss). Comp. Biochem. Physiol. B 137: 49-63.

Yu JH, Li HX, Tang YK, Li JL, et al. (2010). Isolation and expression of myostatin (MSTN) genes, and their polymorphism correlations with body form and average daily gain in Cyprinus carpio var. Jian. J. Agr. Biotechnol. 18: 1062-1072.

Yu JH, Li HX, Tang YK, Li JL, et al. (2011). Isolation, transcript polymorphism and tissue expression of growth hormone receptor genes in Cyprinus carpio var. Jian. Acta Hydrobiol. Sin.35: 218-228.

Zheng X, Tocher DR, Dickson CA, Bell JG, et al. (2004). Effects of diets containing vegetable oil on expression of genes involved in polyunsaturated fatty acid biosynthesis in liver of Atlantic salmon (Salmo salar). Aquaculture 236: 467483. 